\title{
Development of the freeze-thaw processing technique for disaggregation of indurated mudrocks and enhanced recovery of calcareous microfossils
}

\author{
ALICE E. KENNEDY ${ }^{1 *} \&$ ANGELA L. COE $^{1}$ \\ ${ }^{1}$ Department of Environment, Earth and Ecosystems, Centre for Earth, Planetary, Space and Astronomical Research, The Open University, Walton Hall, \\ Milton Keynes, Buckinghamshire MK7 6AA, UK \\ *Corresponding author (e-mail: Alice.Kennedy@open.ac.uk)
}

\begin{abstract}
Microfossil extraction from indurated mudrocks is widely acknowledged as challenging, especially for foraminifera. Here we report development of the freeze-thaw extraction method through the addition of rapid heating, detergent and ultrasound stages. We use indurated mudrock samples from the Toarcian (Early Jurassic) of Yorkshire, UK to assess the effectiveness and develop the freeze-thaw method. We compare our results from freeze-thaw with those from standard foraminifera processing techniques, including the use of hydrogen peroxide. Processing by freeze-thaw increased the degree of mudrock disaggregation and resulted in no damage or dissolution of foraminifera. Following the freeze-thaw method with treatment in white spirit and sodium hexametaphosphate aided the separation of foraminifera from the disaggregated clays and was twice as efficient as pressure washing. Samples processed with hydrogen peroxide contained damaged microfossils and an under representation of delicate calcareous foraminifera. Many other studies of indurated mudrocks have used hydrogen peroxide to extract foraminifera, and this might have resulted in apparently barren intervals. The freeze-thaw method outlined here provides a low-cost, low-risk and successful method of disaggregating and extracting calcareous microfossils from indurated mudrocks. We anticipate our method may be relevant for other fossil groups and merits further development.
\end{abstract}

KEYWORDS: foraminifera, hydrogen peroxide, freeze-thaw, mudrocks, microfossil extraction

GOLD OPEN ACCESS: this article is published under the terms of the CC-BY 3.0 license.

\section{INTRODUCTION}

Indurated organic-rich mudrocks are regarded as difficult for extracting calcareous microfossils, such as foraminifera and ostracods (Green, 2001). Many authors have described the importance of combining chemicals to extract foraminifera from indurated rocks (Duffield \& Warshauer, 1979; Then \& Dougherty, 1983; Aldridge, 1990). For instance, Then \& Dougherty (1983) reported that indurated organic-rich shales were most successfully broken down by using a combination of hydrogen peroxide $\left(\mathrm{H}_{2} \mathrm{O}_{2}\right)$, sodium hypochlorite $(\mathrm{NaClO})$, sodium hydroxide $(\mathrm{NaOH})$ and the detergent Quaternary ' $\mathrm{O}$ ' $\left(\mathrm{C}_{24} \mathrm{H}_{47} \mathrm{~N}_{2} \mathrm{O}_{2} \mathrm{Cl}\right)$. Current foraminifera extraction techniques typically involve a number of chemicals including organic solvents, such as white spirit $\left(\mathrm{C}_{6} \mathrm{H}_{6}\right)$, bleach $(\mathrm{NaClO})$, detergents and hydrogen peroxide $\left(\mathrm{H}_{2} \mathrm{O}_{2}\right)$ (Green, 2001). However, some of these techniques can damage the microfossils (Hodgkinson, 1991; Pingitore et al., 1993). The chemicals previously used and their properties are listed below.

Hydrogen peroxide. This aids disaggregation of the rock by oxidizing the organic matter. The rock sample is soaked in $\mathrm{H}_{2} \mathrm{O}_{2}$ for a variable amount of time; for example, Reolid et al. (2012) used 30\% solution for $24 \mathrm{~h}$ and Hylton (2000, unpublished $\mathrm{PhD}$ thesis, University of Plymouth) soaked samples of Toarcian age in $10 \%$ solution of $\mathrm{H}_{2} \mathrm{O}_{2}$ for an unspecified length of time. Aldridge (1990) described the use of a $10-15 \%$ solution of $\mathrm{H}_{2} \mathrm{O}_{2}$ for 'black shale' disaggregation but similarly does not mention the length of time for treatment. $\mathrm{H}_{2} \mathrm{O}_{2}$ is designated as a hazardous chemical (Table 1).

Petroleum ether, paraffin, white spirits and similar organic solvents. At least some of the organic matter in the samples can be dissolved and hence the rock disaggregated by soaking the sample in an organic solvent such as petroleum or white spirit.
Aldridge (1990) described the use of petroleum ether or similar solvent to extract conodonts and noted that soft or partly indurated mudstones can be disaggregated by soaking them for at least an hour and then covering in hot water, allowing the clay to be sieved off from the fossiliferous fraction. Organic solvents are described by Pingitore et al. (1993) as suitable for extracting fossils made of calcium carbonate $\left(\mathrm{CaCO}_{3}\right)$ as part of routine laboratory techniques. Copestake (1978, unpublished $\mathrm{PhD}$ thesis, University College of Wales) used petroleum spirit to disaggregate Lower Jurassic rocks. Petroleum ether and white spirit are designated as hazardous (Table 1).

Detergents. Detergents can be used to help flocculate the clays; they include Calgon (sodium hexametaphosphate $\left.\left(\mathrm{NaPO}_{3}\right)_{6}\right)$, Decon$90(\mathrm{KOH})$ or Quaternary ' $\mathrm{O}$ ' (2-(8-heptadecenyl)-4,5-dihydro-1, 3-bis(2-hydroxyethyl)-1H-imidazolium chloride or $\mathrm{C}_{24} \mathrm{H}_{47} \mathrm{~N}_{2} \mathrm{O}_{2} \mathrm{Cl}$ ). Duffield \& Warshauer (1979) extracted ostracods and conodonts from Devonian shales using a combination of bleach and Quaternary 'O'. Although Quaternary ' $\mathrm{O}$ ' was successful, the treatment could take up to 7 weeks. Detergents are reported to cause no damage to the thicker-walled microfossils when used in low concentrations (Hodgkinson, 1991). There are no hazards identified for sodium hexametaphosphate in the form of flakes or powder by the European Union Directive 67/548/EEC therefore it is not included in Table 1. Decon-90 has several precautions associated with it (Table 1). As Quaternary ' $\mathrm{O}$ ' was manufactured for use in the mining industry it does not have the same well-defined laboratory hazardous phrases associated with it; none the less the known hazards are listed in Table 1 and it is a strong detergent with environmental restrictions.

Tensides. Tensides (organic detergents) disaggregate the rock by breaking the surface tension bonds of the organic matter with 
A. E. Kennedy \& A. L. Coe

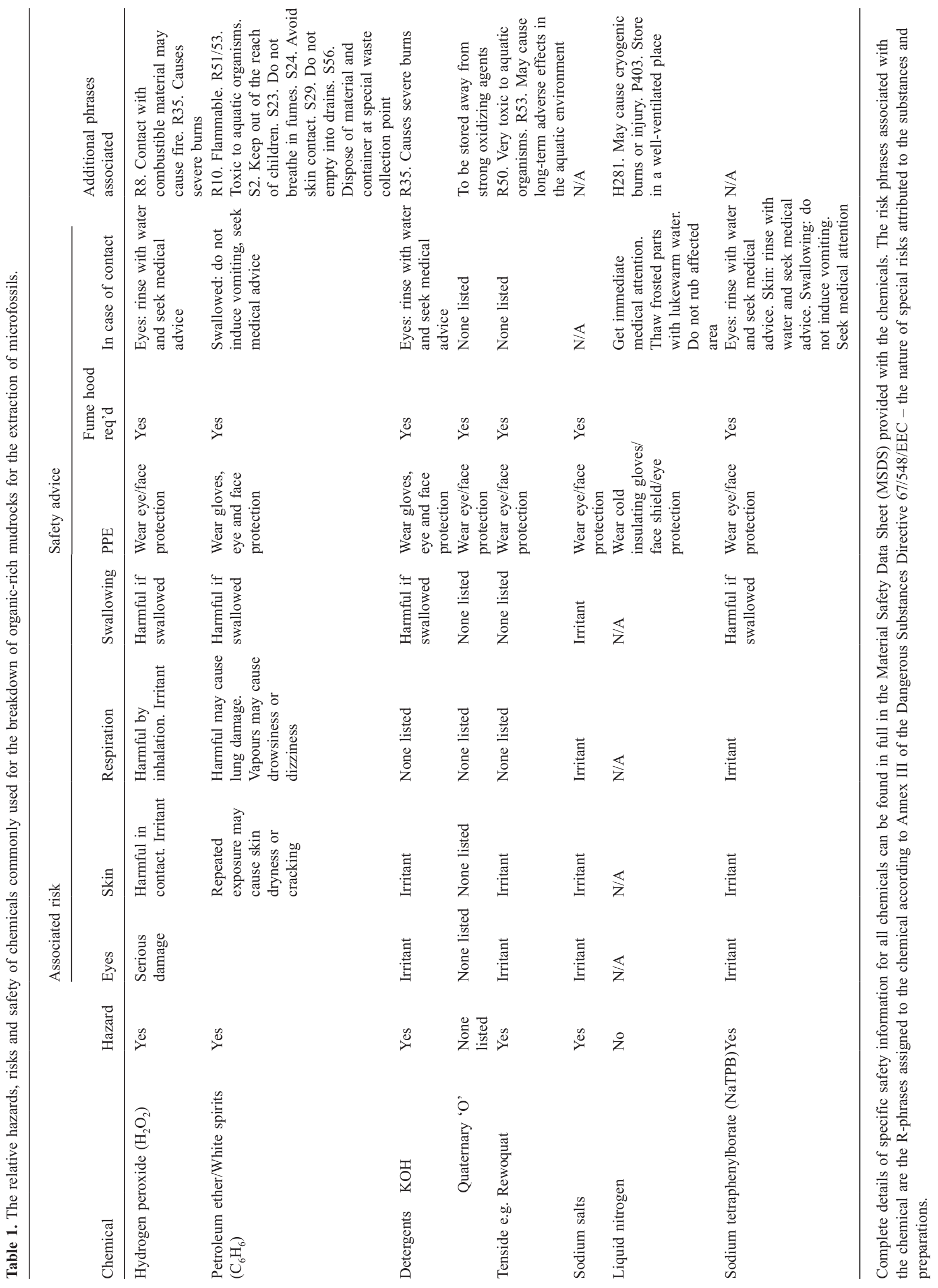


the clay minerals. Moullade et al. (2005) reported processing samples by soaking them in Rewoquat (1-methyl-2-noroleyl-3oleic acid-aminoethyl-imidazolinium-methosulfate) for several days followed by repeated washes in $\mathrm{H}_{2} \mathrm{O}_{2}$ to remove the tenside. Gräfe (2005) disintegrated marine Jurassic marlstones with Rewoquat but did not specify how the samples were washed afterwards. Gräfe (2005) recorded poor foraminifer preservation from this study, which he attributed to taphonomic processes.

Sodium compounds. Sodium compounds disaggregate the rock by mimicking the natural weathering process of shale. The interlayer potassium within the clay mineral structure is replaced with sodium from sodium compounds and causes expansion (Hanken 1979). Sodium tetraphenylborate (NaTPB) and sodium chloride $(\mathrm{NaCl})$ have been described as effective methods to extract intact, clean fossils from indurated mudrocks; however, the cost of NaTPB generally prevents large-scale application (Hanken, 1979). Muller (1990, unpublished PhD thesis, The State University of New Jersey) used Hanken's (1979) method along with dissolution in sodium carbonate to extract benthic foraminifera from Lower Jurassic limestones, marls and shales. NaTPB is assessed as hazardous (Table 1).

Freeze-thaw. Freeze-thaw disaggregates the rocks because as the fluids in the pore spaces of the rock cool and solidify they take up greater volume causing the rock to break apart. Nonchemical disaggregation methods involving the repeated freezing and thawing of rocks have been described previously (Hanna \& Church, 1928; Sohn, 1961; Sohn et al. 1965; Pojeta \& Balanc, 1989). Hanna \& Church (1928) describe successfully disaggregating Pliocene shales by freezing small, water-saturated, samples for several hours or overnight but they provide no further detail. Green (2001) notes that repeated freeze-thawing will disaggregate most shales and that this method has been successful for disaggregating clay-rich sedimentary deposits for the extraction of microfossils. Hanna \& Church (1928) used tap water for the freeze-thawing, whereas Sohn (1961) and Sohn et al. (1965) used dissolved sodium salts solution (including sodium acetate 3-hydrate $\left.\left(\mathrm{CH}_{3} \mathrm{COONa} .3 \mathrm{H}_{2} \mathrm{O}\right)\right)$ and Hinchey \& Green (1994) used liquid nitrogen. The freeze-thaw technique has no chemical safety risks associated (see Table 1 for the safety risks associated with sodium salt solution and liquid nitrogen).

Here we report development and testing of the freeze-thaw technique for the breakdown of indurated mudrocks and extraction of foraminifera. The freeze-thaw method resulted in both a better breakdown of the indurated mudrocks compared to other standard methods and, when combined with white spirit and sodium hexametaphosphate, produced a more abundant and diverse assemblage of the foraminifera preserved in the sediment with no evidence of damage to the tests. To test the freeze-thaw method, we used organic-rich, indurated mudrocks that were deposited prior to and during the Toarcian (Early Jurassic) Oceanic Anoxic Event (Kemp et al. 2005, 2011; Caswell \& Coe, 2013). Our results also extend the range of one foraminifer compared to that reported by Hylton (2000, unpublished PhD thesis, University of Plymouth).

\section{METHOD}

The indurated mudrock samples were collected using a cold chisel and hammer from the Toarcian strata exposed at Hawsker
Bottoms [NZ 94795 07849] and Port Mulgrave [NZ 79803 17669] along the North Yorkshire coast near Whitby, UK. The samples were collected with direct reference to the graphic logs constructed by Angela L. Coe and David B. Kemp and presented in Kemp et al. (2005, 2011). A ceramic mortar and pestle was used to breakdown a known weight of six samples of indurated Toarcian mudrocks of variable composition $\left(0.3-5 \mathrm{wt} \% \mathrm{CaCO}_{3}\right.$; $1.3-8.4 \mathrm{wt} \%$ TOC; $1.78-5.5 \mathrm{wt} \% \mathrm{~S}$; Table 2) into roughly peasized lumps and these were subdivided into aliquots for Methods 1 to 4 .

For the freeze-thaw technique (herein referred to as 'Method 4'), an aliquot of known weight of the pea-sized mudrock lumps was saturated in cold water for $24 \mathrm{~h}$. After decanting off the water and placing the sample in a sealed plastic container, the sample was frozen for approximately $3 \mathrm{~h}$. The sample was then removed from the freezer and rapidly heated by covering it in boiling water for several minutes. This rapid heating is different from previous methods involving freeze-thaw, such as Hanna \& Church (1928), who describe letting the sample reach room temperature. After decanting off the warm water and sieving on a $63 \mu \mathrm{m}$ and a $500 \mu \mathrm{m}$ sieve stacked together under a gentle water jet to extract the fraction between $63 \mu \mathrm{m}$ and $500 \mu \mathrm{m}$, the residue over $500 \mu \mathrm{m}$ was returned to the freezer and the fraction less than $63 \mu \mathrm{m}$ was discarded. The $63-500 \mu \mathrm{m}$ fraction was washed again in the $63 \mu \mathrm{m}$ sieve under a gentle water jet until the water ran clear. The freeze-thaw steps were repeated on the fraction greater than $500 \mu \mathrm{m}$ 15-20 times until almost all the original sample was disaggregated to less than $500 \mu \mathrm{m}$. This is a similar number of freeze-thaw repetitions to that reported by Sohn (1961) and Sohn et al. (1965) although they used sodium salts instead of water. Pojeta \& Balanc (1989) and Green (2001) reported that the processing could be speeded up in a vacuum and that they used a sodium sulphate solution. In our development of the method for mudrocks, we also added a few drops of Decon-90 to the samples during each of the rapid heating steps to increase deflocculation of the clays. Once 15-20 freeze-thaw cycles had been completed, the whole of the $63-500 \mu \mathrm{m}$ fraction collected was subjected to ultrasound for $15-30 \mathrm{~s}$, sieved and washed again using a gentle water jet and then dried.

This new freeze-thaw method (Method 4) was tested against three established methods using the same samples (herein referred to as Methods 1-3). Method 1 involved saturating an aliquot of the pea-sized mudrock lumps of known weight in white spirit for $24 \mathrm{~h}$, decanting off the white spirit and then boiling in a $50 \%$ solution of sodium hexametaphosphate for 25 minutes. The samples were then soaked in $30 \% \mathrm{H}_{2} \mathrm{O}_{2}$ in a water bath for up to an hour. This method is similar to that used by Hylton (2000, unpublished $\mathrm{PhD}$ thesis, University of Plymouth) and Reolid et al. (2012). Method 2 was the same as Method 1 but the $\mathrm{H}_{2} \mathrm{O}_{2}$ stage was omitted. Method 3 involved soaking an aliquot of the peasized mudrock lumps of known weight in Rewoquat (Gräfe, 2005; Moullade et al. 2005) for 1 week before repeated washes in $\mathrm{H}_{2} \mathrm{O}_{2}$.

Method 4 produced a very high degree of disaggregation of the mudrocks into particles $<500 \mu \mathrm{m}$ (see 'Results' and 'Discussion') and some to $<63 \mu \mathrm{m}$; however, it left many aggregated clay particles in the $63-500 \mu \mathrm{m}$ fraction. Two techniques were tested to break down more of the clay aggregates from the $63-500 \mu \mathrm{m}$ fraction. The first was to combine Method 4 with Method 2. This was done by soaking the whole $63-500 \mu \mathrm{m}$ fraction recovered from 


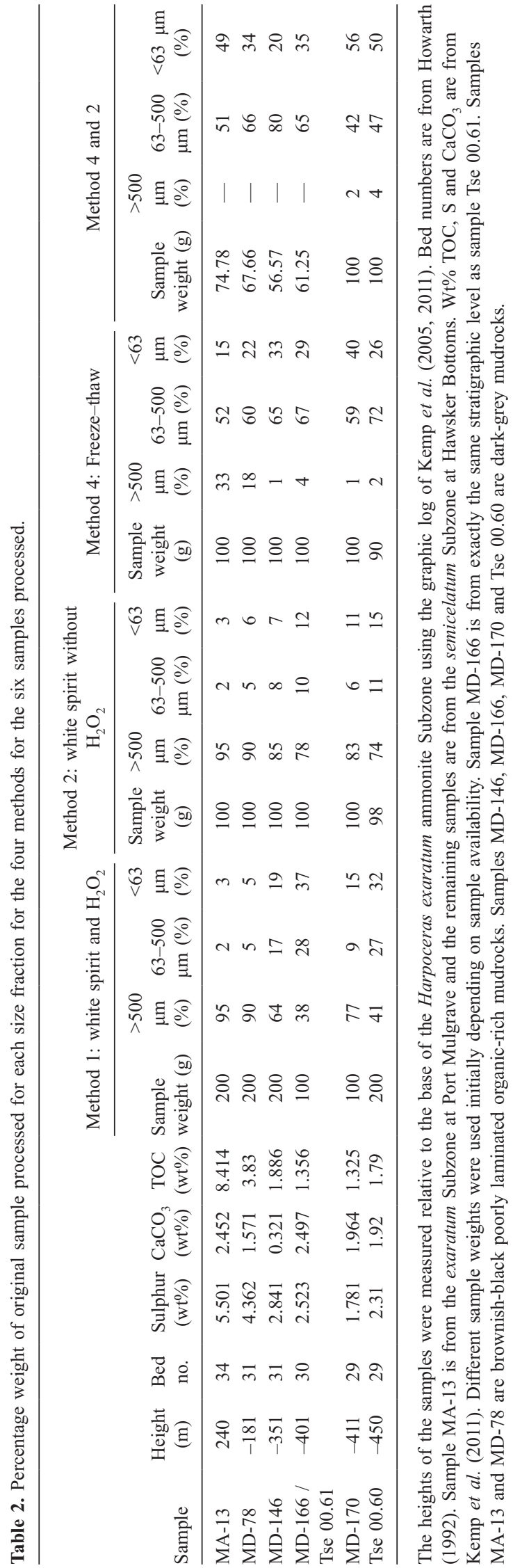

Method 4 in white spirit overnight prior to the final drying stage. The sample was then boiled in sodium hexametaphosphate before sieving and drying the $63-500 \mu \mathrm{m}$ fraction. The second method of breaking down the clay aggregates was to use a high pressure $\left(0.018 \mathrm{ls}^{-1}\right)$ finely dispersed water spray for at least $45 \mathrm{~min}$ on the $63-500 \mu \mathrm{m}$ fraction whilst it was in the $63 \mu \mathrm{m}$ sieve; this technique was tested on two samples only (Tse 00.60 and MD-170).

The $63-500 \mu \mathrm{m}$ fraction of the samples processed by all the different methods was picked to $10 \mathrm{~g}$ or to 300 specimens (whichever was completed first) using an Olympus SZX12 research stereomicroscope and the fossils were mounted on to slides using water-soluble Gum Tragacanth glue. The preservation of the foraminifera and other calcareous and pyritic microfossils was examined further using the FEI Quanta 200 3D scanning electron microscope (SEM) at the Open University. For the SEM analysis the microfossils were coated in $c .15 \mathrm{~nm}$ of carbon and recorded using an accelerating voltage of $20 \mathrm{kV}$ and a beam current of $0.6 \mathrm{nA}$. The software PAST (http://folk.uio.no/ohammer/past/) was used to calculate a range of diversity indices.

\section{RESULTS}

The degree of disaggregation of the samples from each of the methods, i.e. the percentage of the sample completely broken up into $<500 \mu \mathrm{m}$ particles, varied considerably from $5 \%$ (Method 1 , sample MA-13) to 99\% (Method 4, sample MD-170) (Table 2, Fig. 1). For all samples, the new freeze-thaw technique (Method 4) produced the highest degree of disaggregation and Method 2 produced the lowest. Method 3 was difficult to use and disaggregation was unsuccessful for sample MD-166, although it demonstrated a $77 \%$ disaggregation of sample Tse $00.60(67 \%$ of the sample was the $63-500 \mu \mathrm{m}$ foraminifera yielding fraction). A combination of Methods 4 and 2, yielded a greater loss of clay particles $(<63 \mu \mathrm{m}$ fraction) from the $63-500 \mu \mathrm{m}$ fraction than from Method 4 alone (Fig. 2). The average percentage reduction in the weight of the fossiliferous fraction through clay loss from the application of Method 2 after Method 4 was 20\% (Fig. 2). In contrast the high-pressure washing of samples Tse 00.60 and MD-170 produced an average percentage reduction in the weight of the $63-500 \mu \mathrm{m}$ fossiliferous fraction of $10 \%$ through clay loss.

The raw foraminifer abundance and diversity data are shown in Tables 3 and 4 and, Figures 3 and 4. Samples MA-13 and MD-78 are barren of foraminifera (and, therefore, not shown in Table 3). Because of the wide variation in the amount of disaggregation and picking to either $10 \mathrm{~g}$ or 300 specimens, we also calculated the amount of foraminifera predicted from each sample if the whole processed sample was picked and $100 \mathrm{~g}$ was the initial weight. We calculated this by using the raw foraminifer abundance data in the fossiliferous fraction and multiplying it by the amount of sample available to pick through (i.e. the difference between the size of the picked $63-500 \mu \mathrm{m}$ fraction and the size of the remaining $63-500 \mu \mathrm{m}$ residue left to pick). We then normalized to the initial $100 \mathrm{~g}$ weight by multiplying those samples with a different start weight by the difference in weight. These results are shown in Table 5 and Figure 5. The range of diversity indices obtained from the software package, PAST, are shown in Figure 4. The diversity indices used were the Simpson, Margalef, Shannon H, Menhinick and Fisher alpha, as well as the dominance and evenness for each sample (see Hammer \& Harper (2006) for further details on diversity indices). The raw data for 
Freeze-thaw processing for microfossil extraction

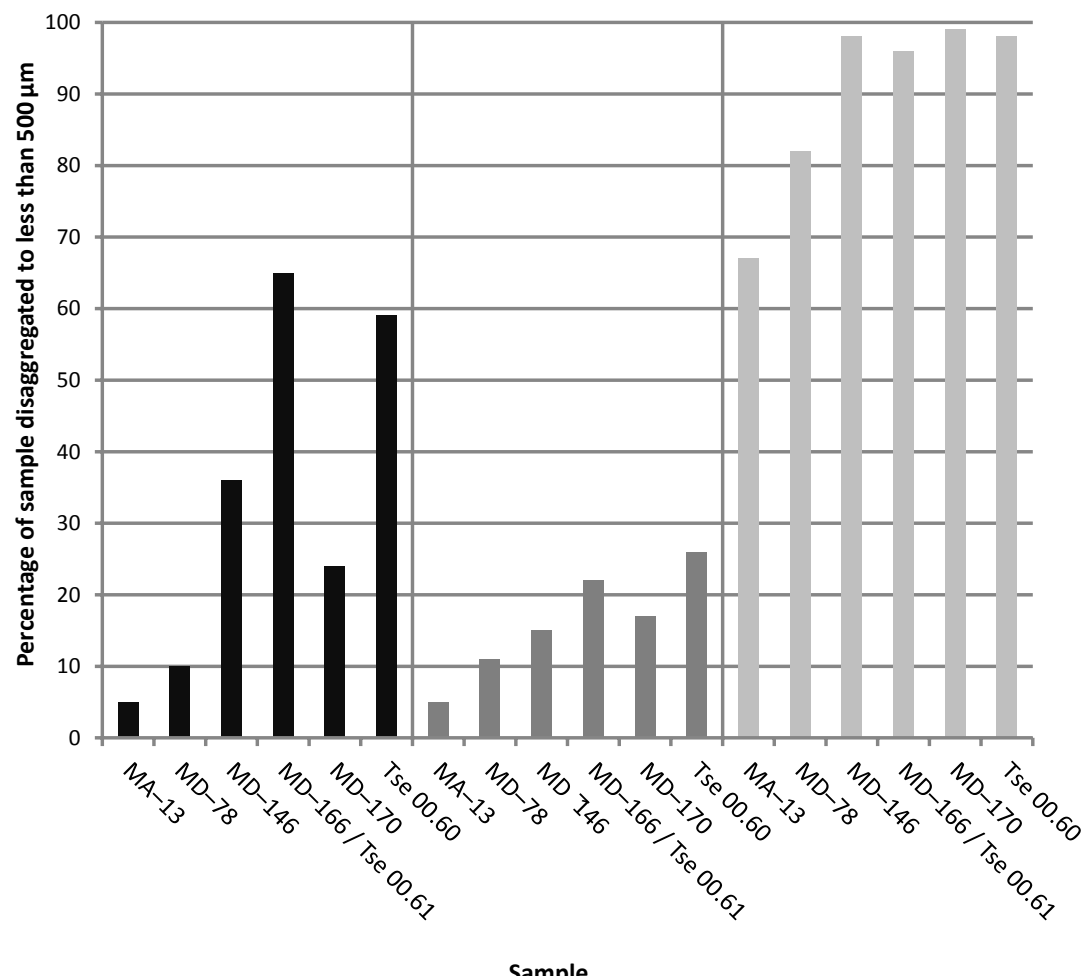

Method 1

Method 2

Method 4

Fig. 1. Histogram showing the percentage disaggregation of samples to less than $500 \mu \mathrm{m}$ from the four different methods.

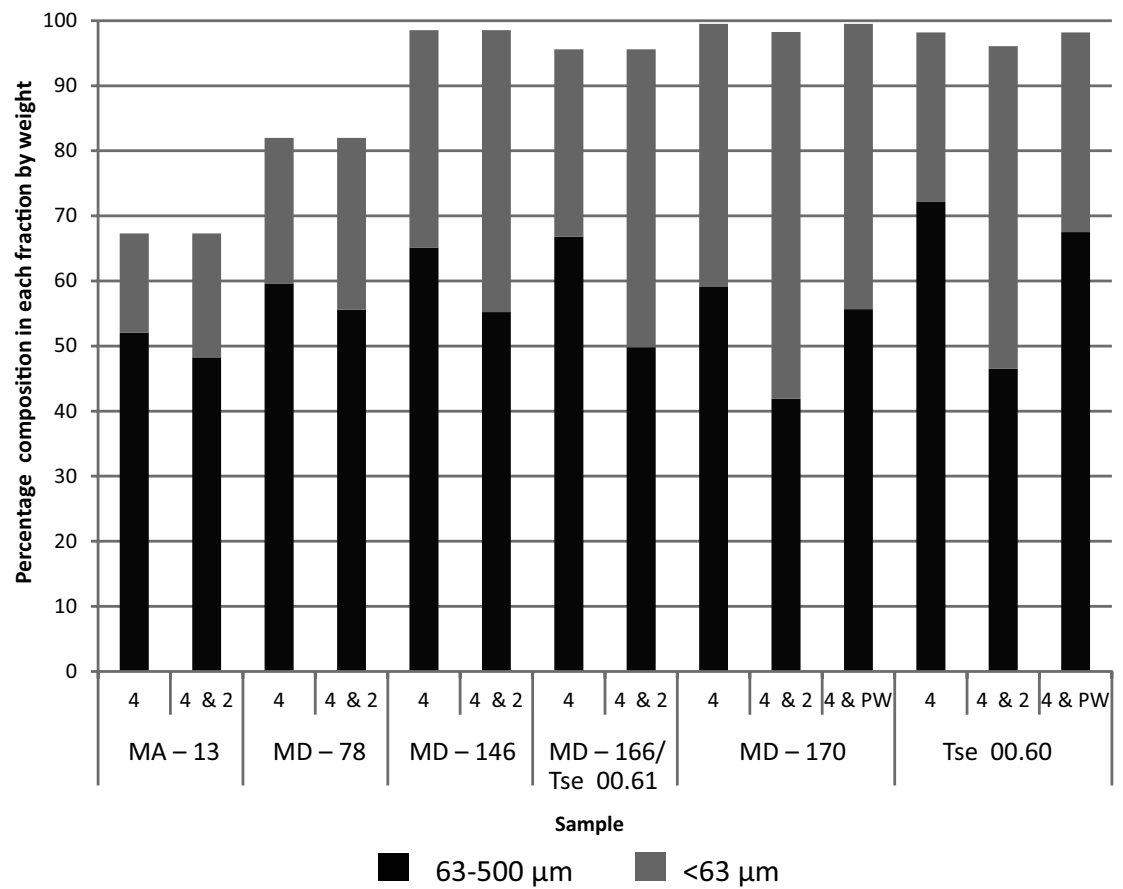

Fig. 2. Histogram showing the percentage composition of the fractions smaller than $500 \mu \mathrm{m}$ and its distribution between the $<63 \mu \mathrm{m}$ clay fraction and 63-500 $\mu \mathrm{m}$ fraction from which the foraminifera could be extracted. The histogram shows, for all samples, Method 4 and Method 4 combined with Method 2; it also shows for samples MD-170 and Tse 00.60 only, Method 4 combined with high-pressure water spray (PW). The 63-500 $\mu \mathrm{m}$ fraction from Method 4 was used to test for further clay removal through the addition of Method 2 for samples MA-13, MD-78, MD-146 and MD-166/Tse 00.61 and through pressure washing for samples MD-170 and Tse 00.60. For samples MD-170 and Tse 00.60 a new aliquot of the samples was used to test Method 4 combined with Method 2. 
Table 3. Raw foraminifer presence and abundance data.

\begin{tabular}{|c|c|c|c|c|c|c|c|c|c|c|c|c|c|c|c|c|}
\hline \multirow{2}{*}{$\begin{array}{l}\text { Sample name } \\
\text { Method of processing }\end{array}$} & \multicolumn{4}{|c|}{ MD-146 } & \multicolumn{4}{|c|}{ MD-166/Tse 00.61} & \multicolumn{4}{|c|}{ MD-170 } & \multicolumn{4}{|c|}{ Tse 00.60} \\
\hline & 1 & 2 & 4 & $4 \& 2$ & 1 & 2 & 4 & $4 \& 2$ & 1 & 2 & 4 & $4 \& 2$ & 1 & 2 & 4 & $4 \& 2$ \\
\hline Astacolus matutina & 0 & 0 & 0 & 0 & 0 & 0 & 0 & 0 & 0 & 0 & 0 & 0 & 0 & 0 & 0 & 1 \\
\hline Astacolus primus & 0 & 2 & 1 & 0 & 0 & 6 & 0 & 11 & 0 & 1 & 0 & 4 & 0 & 3 & 1 & 11 \\
\hline A. primus (pyritized) & 0 & 4 & 0 & 0 & 3 & 5 & 1 & 0 & 2 & 0 & 2 & 5 & 2 & 3 & 1 & 1 \\
\hline Astacolus primus sp. & 0 & 0 & 0 & 0 & 0 & 0 & 0 & 4 & 0 & 0 & 0 & 0 & 0 & 0 & 0 & 0 \\
\hline Brizalina liassica & 10 & 15 & 6 & 8 & 51 & 115 & 50 & 108 & 2 & 39 & 2 & 28 & 30 & 65 & 23 & 98 \\
\hline B. liassica (pyritized) & 0 & 2 & 2 & 0 & 0 & 16 & 0 & 5 & 2 & 3 & 0 & 1 & 1 & 9 & 0 & 3 \\
\hline Citharina colliezi & 0 & 0 & 0 & 0 & 0 & 0 & 0 & 0 & 0 & 0 & 0 & 0 & 0 & 3 & 0 & 0 \\
\hline Dentalina varians & 0 & 7 & 3 & 7 & 3 & 3 & 2 & 3 & 13 & 5 & 1 & 0 & 1 & 8 & 2 & 2 \\
\hline Eoguttulina liassica & 0 & 0 & 1 & 0 & 0 & 17 & 1 & 4 & 1 & 4 & 0 & 0 & 0 & 0 & 0 & 8 \\
\hline E. liassica (pyritized) & 1 & 108 & 41 & 18 & 0 & 30 & 4 & 2 & 72 & 45 & 4 & 3 & 6 & 39 & 0 & 8 \\
\hline Haplophragmoides cf. kingakensis & 0 & 0 & 0 & 0 & 0 & 0 & 0 & 5 & 0 & 0 & 0 & 0 & 0 & 0 & 0 & 0 \\
\hline Haplophragmoides kingakensis & 0 & 1 & 0 & 0 & 0 & 0 & 0 & 0 & 0 & 0 & 0 & 0 & 0 & 0 & 0 & 0 \\
\hline H. kingakensis (pyritized) & 3 & 8 & 4 & 0 & 1 & 5 & 0 & 0 & 2 & 1 & 0 & 0 & 2 & 1 & 0 & 0 \\
\hline Marginulina prima ?spinata & 0 & 0 & 3 & 0 & 0 & 2 & 0 & 0 & 0 & 3 & 0 & 9 & 0 & 1 & 0 & 1 \\
\hline M. prima ?spinata (pyritized) & 0 & 0 & 0 & 0 & 0 & 0 & 0 & 0 & 1 & 0 & 1 & 0 & 0 & 0 & 0 & 0 \\
\hline Prodentalina terquemi & 0 & 1 & 0 & 1 & 0 & 1 & 1 & 1 & 1 & 11 & 3 & 15 & 0 & 0 & 1 & 1 \\
\hline P. terquemi (pyritized) & 0 & 0 & 0 & 0 & 0 & 1 & 0 & 1 & 0 & 0 & 0 & 2 & 0 & 0 & 0 & 0 \\
\hline Reinholdella macfadyeni & 1 & 1 & 1 & 3 & 52 & 82 & 9 & 27 & 10 & 13 & 12 & 69 & 0 & 0 & 0 & 46 \\
\hline R. macfadyeni (pyritized) & 1 & 1 & 1 & 0 & 20 & 90 & 10 & 19 & 8 & 16 & 4 & 71 & 0 & 4 & 2 & 53 \\
\hline Reinholdella pachyderma & 1 & 1 & 0 & 0 & 24 & 25 & 0 & 7 & 2 & 22 & 10 & 8 & 0 & 1 & 0 & 18 \\
\hline R. pachyderma (pyritized) & 0 & 1 & 0 & 0 & 24 & 15 & 6 & 1 & 3 & 9 & 8 & 9 & 0 & 1 & 2 & 9 \\
\hline Reinholdella planiconvexa & 0 & 0 & 0 & 0 & 0 & 0 & 0 & 0 & 0 & 0 & 0 & 0 & 0 & 0 & 0 & 0 \\
\hline R. planiconvexa (pyritized) & 0 & 0 & 0 & 0 & 0 & 6 & 0 & 0 & 1 & 0 & 0 & 3 & 0 & 0 & 0 & 0 \\
\hline Reinholdella sp. & 0 & 0 & 1 & 0 & 50 & 20 & 4 & 15 & 2 & 2 & 2 & 15 & 2 & 0 & 0 & 2 \\
\hline Reinholdella sp. (pyritized) & 0 & 0 & 2 & 0 & 15 & 12 & 6 & 15 & 6 & 6 & 1 & 5 & 0 & 0 & 0 & 2 \\
\hline Spirillina infirma (pyritized) & 0 & 1 & 0 & 0 & 0 & 1 & 0 & 1 & 0 & 0 & 0 & 0 & 0 & 1 & 0 & 0 \\
\hline Verneulinoides cf. subvitreus (pyritized) & 0 & 1 & 1 & 0 & 0 & 0 & 0 & 0 & 0 & 0 & 0 & 0 & 0 & 0 & 0 & 0 \\
\hline Ostracod & 0 & 0 & 0 & 0 & 1 & 1 & 0 & 2 & 1 & 0 & 0 & 0 & 0 & 0 & 0 & 3 \\
\hline Unknown pyritized foram. & 0 & 0 & 4 & 0 & 0 & 0 & 0 & 0 & 0 & 0 & 0 & 0 & 0 & 0 & 0 & 0 \\
\hline Microbivalve (pyritized) & 5 & 28 & 36 & 26 & 26 & 39 & 20 & 29 & 14 & 25 & 9 & 12 & 29 & 64 & 15 & 24 \\
\hline Microgastropod & 1 & 1 & 9 & 10 & 1 & 1 & 2 & 0 & 5 & 2 & 9 & 16 & 13 & 12 & 11 & 3 \\
\hline Microgastropod (pyritized) & 13 & 38 & 25 & 29 & 6 & 17 & 7 & 16 & 35 & 19 & 19 & 26 & 53 & 183 & 22 & 18 \\
\hline
\end{tabular}

Note: the amount of sample processed and picked varies; see Tables 2 and 4 for further details.

each foraminifer species for each method are shown in Table 3. Species present in consistently high numbers regardless of processing method are Reinholdella macfadyeni (Ten Dam, 1952) and Brizalina liassica (Terquem, 1858).

Microfossils from samples processed with Method 1 using $\mathrm{H}_{2} \mathrm{O}_{2}$ were degraded in three ways:

(i) pyritized fossils were damaged (Figs 6a and 7a) compared to those subjected to freeze-thaw (Figs $6 \mathrm{~b}$ and $7 \mathrm{~b}$ );

(ii) for the majority of samples there was a decreased abundance, particularly of delicate foraminifera;

(iii) the diversity was lowest, except for sample MD-170 where the diversity was comparable with the other methods. In all samples processed without $\mathrm{H}_{2} \mathrm{O}_{2}$ several individuals of the small delicate foraminifer Eoguttulina liassica (Strickland 1864) were found in both pyritized (Fig. 7a, b) and nonpyritized forms (Fig. 7c) whereas only one of the four samples processed with Method 1 using $\mathrm{H}_{2} \mathrm{O}_{2}$ was found to contain a single specimen of the non-pyritized form of
E. liassica. The six species that are absent from samples processed with $\mathrm{H}_{2} \mathrm{O}_{2}$ but found using other methods are: Reinholdella (?) planiconvexa (Fuchs, 1989), Spirillina infima (Strickland, 1864), Verneuilinoides cf. subvitreus (Nagy \& Johansen, 1991), Astacolus matutina (d'Orbigny, 1850), Citharina colliezi (Terquem 1866) and Haplophragmoides cf. kingakensis (Tappan, 1955). Samples processed with $\mathrm{H}_{2} \mathrm{O}_{2}$ with only one individual of a species present in $10 \mathrm{~g}$ or up to 300 counts of the picked residue in addition to E. liassica are Prodentalina terquemi (d'Orbigny, 1839) and Marginulina prima ?spinata (Terquem, 1858).

As it was clear that $\mathrm{H}_{2} \mathrm{O}_{2}$ was damaging and, in some cases, dissolving, the fossils and the last stage of the Rewoquat (Method 3 ) involved multiple washings in $\mathrm{H}_{2} \mathrm{O}_{2}$, Method 3 was not tested further.

Table 6 shows the relative costs and processing time for each method. Methods 1 and 2 are the fastest in terms of total time taken for processing, but in terms of 'hands on' time, Methods 2 
Freeze-thaw processing for microfossil extraction

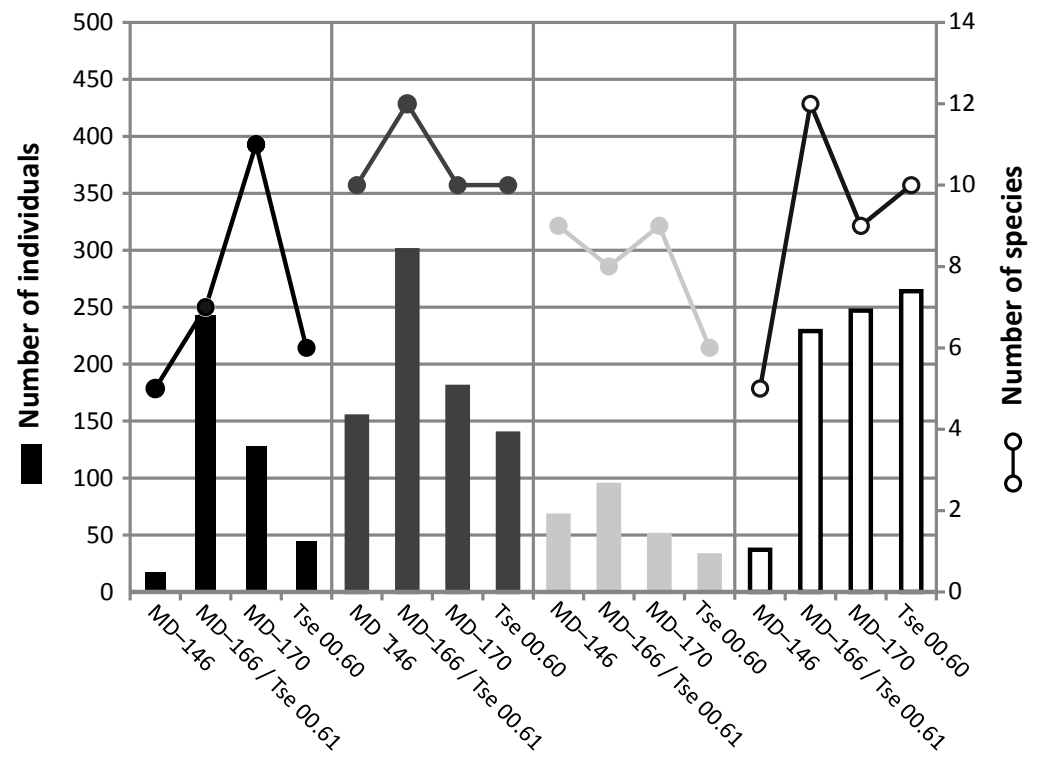

Sample

Method 1

Method 2

Method 4

Method 4 \& 2

Fig. 3. Histogram showing the abundance of foraminifera and line graph showing the number of species for each of the samples processed by each of the methods.
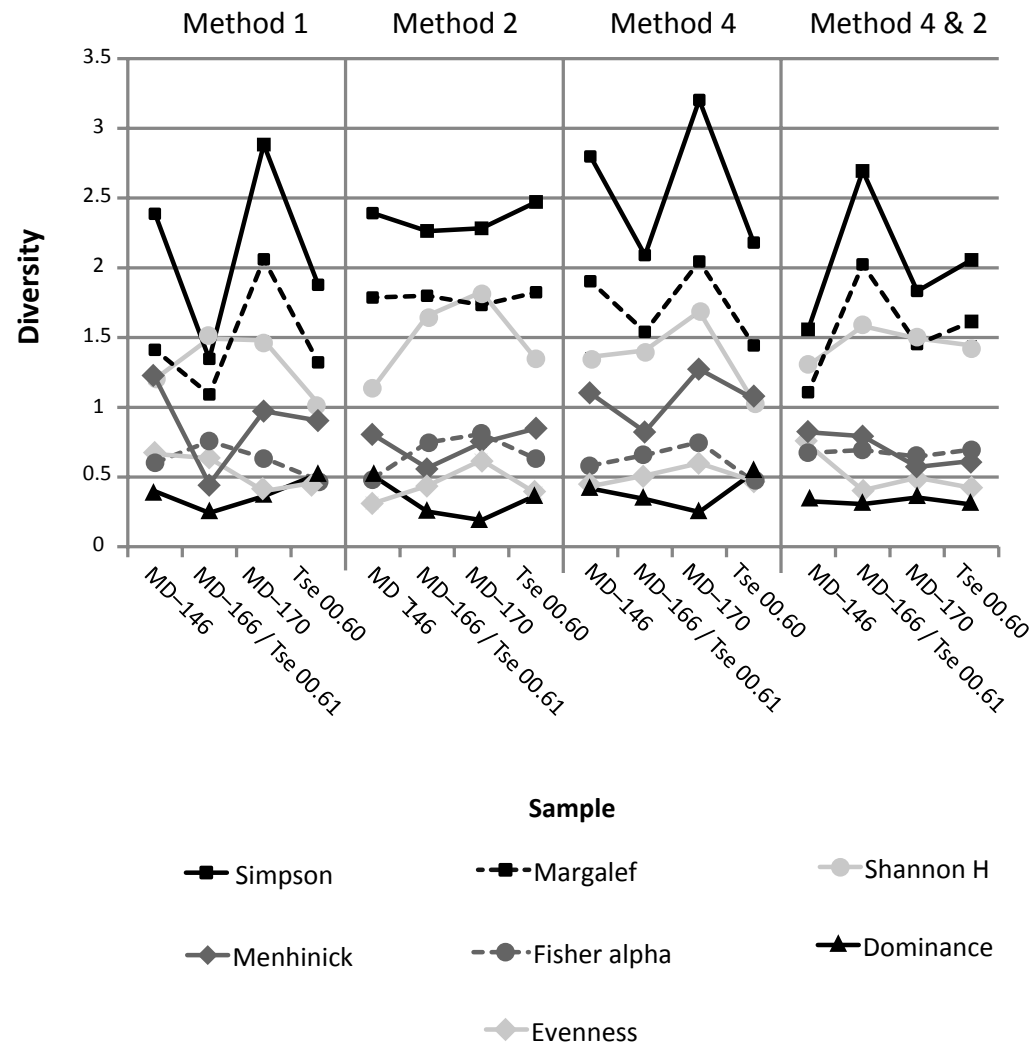

Fig. 4. The diversity of foraminifer assemblages in picked sedimentary rock using the Simpson, Margalef, Shannon H, Menhinick and Fisher alpha indices as well as the dominance and evenness for each sample calculated using PAST software. 
Table 4. The fossil abundance and diversity in the $63-500 \mu \mathrm{m}$ residue picked to $10 \mathrm{~g}$ or 300 individuals (whichever was sooner).

\begin{tabular}{|c|c|c|c|c|c|c|c|c|c|c|c|c|c|c|c|c|}
\hline Sample & A & B & $\mathrm{C}$ & $\mathrm{D}$ & A & B & $\mathrm{C}$ & $\mathrm{D}$ & A & $\mathrm{B}$ & $\mathrm{C}$ & $\mathrm{D}$ & A & $\mathrm{B}$ & $\mathrm{C}$ & $\mathrm{D}$ \\
\hline MA-13 & 0 & 0 & 0 & 2 & 0 & 0 & 0 & 0 & 0 & 0 & 0 & 0 & 0 & 0 & 0 & 1 \\
\hline MD-78 & 0 & 0 & 0 & $>300$ & $0^{*}$ & $0^{*}$ & $0^{*}$ & $107 *$ & 0 & 0 & 0 & $>300$ & 0 & 0 & 0 & $>300$ \\
\hline MD-146 & 17 & 5 & 19 & 81 & $154^{*}$ & $10^{*}$ & $67^{*}$ & $166^{*}$ & 67 & 8 & 70 & 61 & 37 & 5 & 65 & 120 \\
\hline Tse 00.60 & 44 & 6 & 95 & 116 & 139 & 11 & 259 & $>300$ & 32 & 7 & 48 & 52 & 264 & 10 & 45 & 176 \\
\hline
\end{tabular}

*Not picked to $10 \mathrm{~g}$ due to insufficient sample remaining after disaggregation (see Table 2). The columns are as follows: A: abundance of foraminifera in $10 \mathrm{~g}$ (unless *); B: diversity of foraminifera; C: abundance of ostracods, microgastropods and microbivalves; D: abundance of prasinophytes (bluegreen algae of the group Tasmanitids). Sample MA-13 yielded no foraminifera from any method.

Table 5. The abundance and predicted abundance of foraminifera in the residue.

\begin{tabular}{|c|c|c|c|c|c|c|c|c|}
\hline Sample & A & PA & A & PA & A & PA & A & PA \\
\hline MD-78 & 0 & 0 & $0^{*}$ & 0 & 0 & 0 & 0 & 0 \\
\hline MD-146 & 17 & 28 & $154^{*}$ & 155 & 67 & 664 & 37 & 166 \\
\hline MD-166/Tse 00.61 & 243 & 640 & 452 & 630 & 94 & 622 & 229 & 892 \\
\hline
\end{tabular}

A: abundance of foraminifera in $10 \mathrm{~g}$ or the first 300 as in Table 3; PA: the predicted abundance of foraminifera if all $63-500 \mu \mathrm{m}$ fraction initially processed, was picked. Note: the initial sample weight used was normalized to $100 \mathrm{~g}$ in all cases; * as Table 4.

and 4 are the shortest and Method 1 is the longest. High-pressure washing adds a minimum of $45 \mathrm{~min}$. At the current (2013) costs for chemicals, Method 4 is the cheapest and Method 1 is the most expensive at approximately double the cost of Method 2 or, Method 4 combined with Method 2.

\section{DISCUSSION}

The effectiveness of the different methodologies was assessed as a function of: (1) the degree to which the sample was disaggregated; (2) the abundance and diversity of extracted foraminifera; and (3) the quality of preservation of the microfossils extracted from the sample.

Method 4 was the most effective method for disaggregating the mudrocks, and consistently disaggregated over $65 \%$ of the sample (Table 2; Fig. 1). In comparison, Method 2 was the worst and disaggregated less than $25 \%$ of the sample to $<500 \mu \mathrm{m}$. However, Method 4 left the microfossils in the $63-500 \mu \mathrm{m}$ fraction very diluted by aggregated clay particles which could not be quickly removed by high-pressure washing. Application of Method 2 after Method 4, on the $63-500 \mu \mathrm{m}$ residue extracted from Method 4, concentrated the microfossils by allowing further disaggregation of the $63-500 \mu \mathrm{m}$ aggregates into clay particles and microfossils from which the clay particles could be removed by gentle washing over a $63 \mu \mathrm{m}$ sieve. The application of Method 2 after Method 4 was twice as effective at breaking down the aggregates and removing the clays than $45 \mathrm{~min}$ of high-pressure washing (Fig. 2). Ultrasound preparation of the whole of the $63-500 \mu \mathrm{m}$ fraction at the end of Method 4 also helped to deflocculate the clays. Hodgkinson (1991) reported that ultrasound preparation damaged agglutinated foraminifera, but no evidence of damage was found on the few specimens of agglutinated foraminifera extracted in the samples tested here.

Method 2, and Method 4 combined with 2, yielded within uncertainty the highest raw abundances of all foraminifer species (Table 4; Fig. 5). Method 4 alone did not yield such high raw abundances as Method 4 combined with 2 because the first $10 \mathrm{~g}$ picked using Method 4 was more diluted by $63-500 \mu \mathrm{m}$ clay aggregates due to the success rate of the disaggregation to particles of $<500 \mu \mathrm{m}$. It follows that Method 4 combined with Method 2 yielded the highest predicted foraminifer counts (Fig. 5) because more of the original sample was disaggregated by the freeze-thaw (compared to Method 2 alone) and the use of both methods concentrated the foraminifera in the raw counts. The success of the freeze-thaw method in both disaggregating more of the sample and not damaging the fossils clearly increases the potential number of foraminifera that are available for picking. However, the efficient breakdown of the rock makes picking more time consuming because aggregated clay particles remain in the 63$500 \mu \mathrm{m}$ fraction even after Method 4 and Method 2 are combined.

The different diversity indices from PAST are indistinguishable between all the methods within the limits of natural variance and there is no clear relationship with either wt $\%$ TOC, or wt $\%$ $\mathrm{CaCO}_{3}$ or $\mathrm{wt} \% \mathrm{~S}$ for the few samples tested (Fig. 4). However, the raw abundance and diversity counts for the foraminifer assemblages (Table 3) show that Method 1 has a lower abundance of 


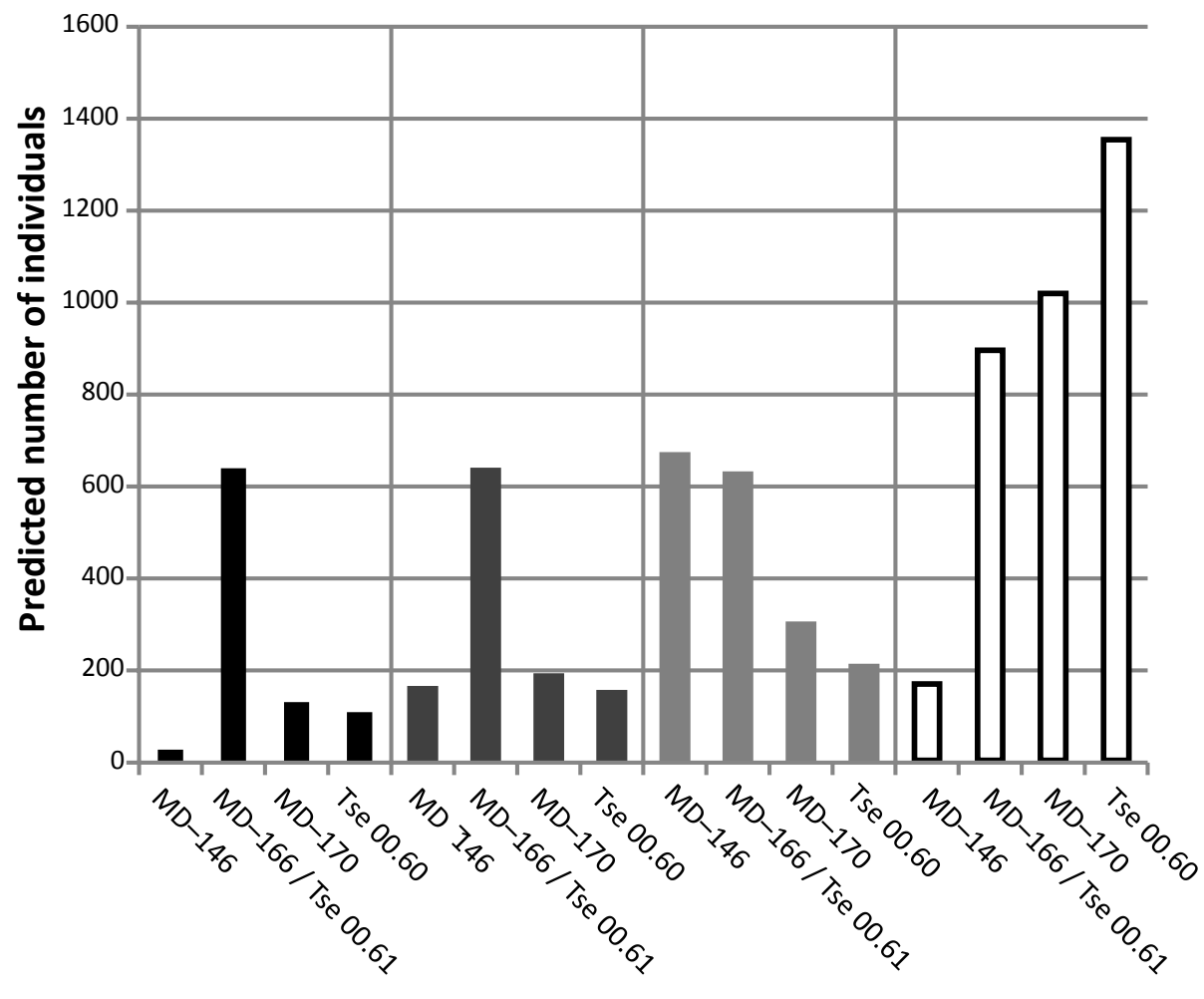

\section{Sample}

Method 1

Method 2

Method 4

Method 4 \& 2

Fig. 5. The predicted number of foraminifera in the $63-500 \mu \mathrm{m}$ fraction assuming the initial processed weight was $100 \mathrm{~g}$ and that the entire sample which was successfully disaggregated was picked for foraminifera.
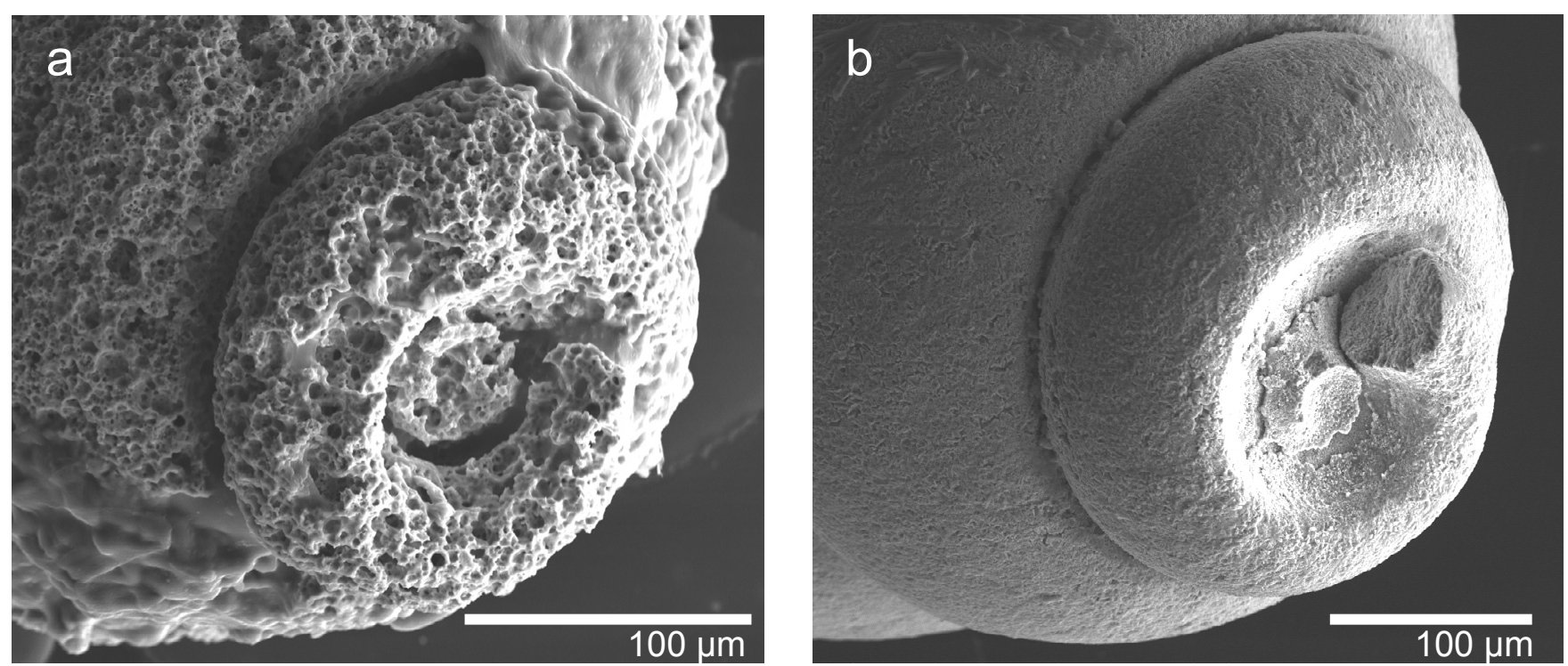

Fig. 6. (a) SEM image of a pyritized microgastropod processed with $\mathrm{H}_{2} \mathrm{O}_{2}$ showing pitting and dissolution damage. (b) SEM image of pyritized microgastropod processed by freeze-thaw.

the 'rarer species' and that some species are absent altogether and we interpret this to be the result of complete oxidation and dissolution by $\mathrm{H}_{2} \mathrm{O}_{2}$. In contrast, Method 4 combined with 2 generally has a higher abundance of all species.
Our SEM work shows that $\mathrm{H}_{2} \mathrm{O}_{2}$ resulted in significant damage to pyritized microfossils and our abundance and diversity data show that $\mathrm{CaCO}_{3}$ microfossils were significantly reduced in number or absent when extracted using $\mathrm{H}_{2} \mathrm{O}_{2}$. That $\mathrm{H}_{2} \mathrm{O}_{2}$ could 

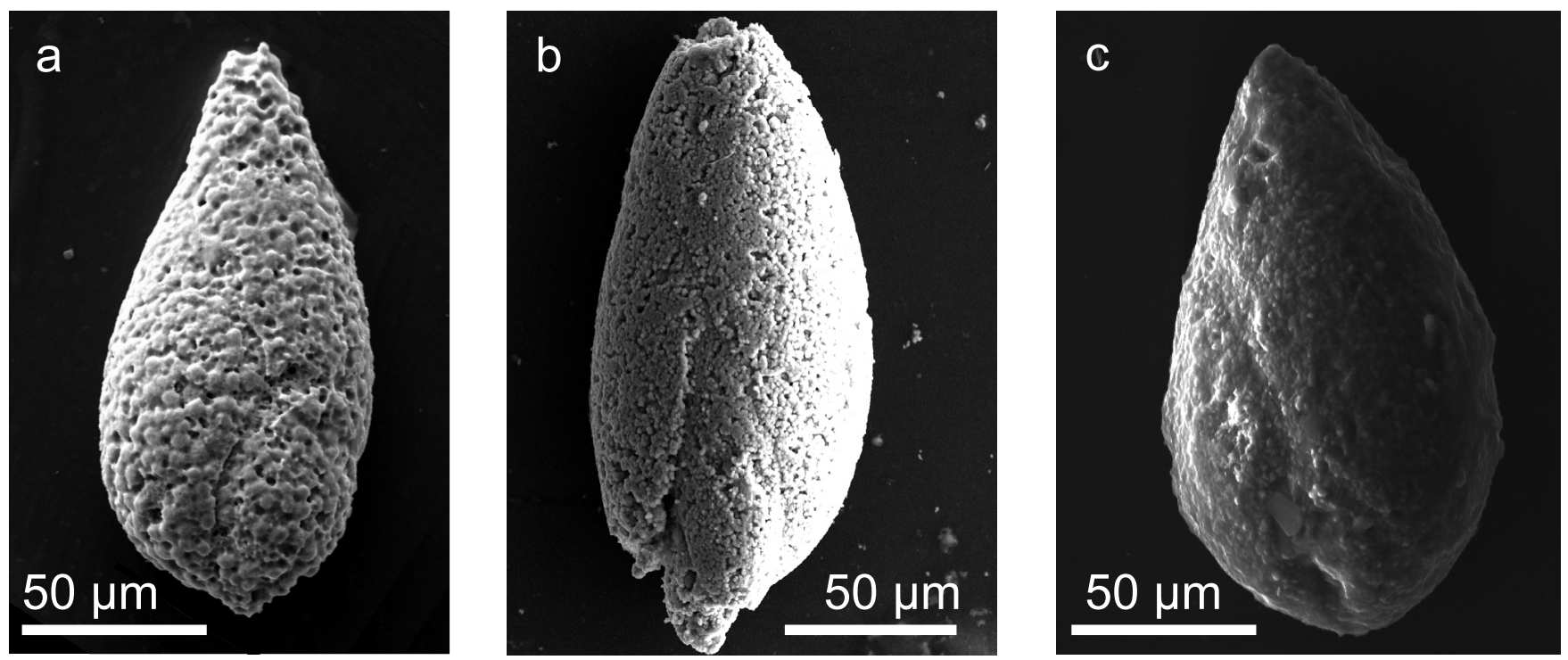

Fig. 7. SEM images of the foraminifer Eoguttulina liassica (Strickland, 1864): (a) pyritized, and processed with $\mathrm{H}_{2} \mathrm{O}_{2}$; (b) pyritized, and processed without $\mathrm{H}_{2} \mathrm{O}_{2}$; (c) non-pyritized, and processed without $\mathrm{H}_{2} \mathrm{O}_{2}$.

Table 6. Relative cost and processing time for each method tested in this paper.

\begin{tabular}{|c|c|c|c|c|c|}
\hline & Method 1 & Method 2 & Method 4 & Method 4 and 2 & High-pressure washing \\
\hline $\begin{array}{l}\text { Hands-on time per } \\
\text { sample }\end{array}$ & $1 \mathrm{~h} 30 \mathrm{~min}$ & $30 \mathrm{~min}$ & $30 \mathrm{~min}$ & $1 \mathrm{~h}$ & $45 \mathrm{~min}$ \\
\hline
\end{tabular}

Method 1 used white spirit, sodium hexametaphosphate and hydrogen peroxide, Method 2 used white spirit and sodium hexametaphosphate, Method 4 used freeze-thaw. See text for further details.

cause damage to $\mathrm{CaCO}_{3}$ was also noted by Hodgkinson (1991) and Pingitore et al. (1993). Reolid et al. (2012, p.91) described ornamented foraminifera tests that they had extracted as 'pitted, smooth or polished surfaces on the test periphery' and damage to final chambers of the test. We note that this pitting is similar to that which we observed on SEM images of the pyritized microfossils processed using $\mathrm{H}_{2} \mathrm{O}_{2}$ (Figs 6a and 7a) and suggest that the damage Reolid et al. (2012) observed may have been caused by the $\mathrm{H}_{2} \mathrm{O}_{2}$. We also suggest that the poor foraminifera preservation reported by Gräfe (2005) and attributed to taphonomic process could be instead due to $\mathrm{H}_{2} \mathrm{O}_{2}$ treatment if this was used in their processing. The lower abundance of $\mathrm{CaCO}_{3}$ forms observed in the samples we processed using $\mathrm{H}_{2} \mathrm{O}_{2}$ is interpreted to result from dissolution of delicate foraminifera, such as E. liassica and Haplophragmoides cf. kingakensis. Under the SEM, some of the $\mathrm{CaCO}_{3}$ forms of $R$. macfadyeni and Brizalina liassica exhibited evidence of dissolution which we interpret to be due to the use of $\mathrm{H}_{2} \mathrm{O}_{2}$.

Although Hodgkinson (1991) suggested sodium hexametaphosphate in high concentrations could cause damage to foraminifer tests, there was no visible damage to those processed with methods using sodium hexametaphosphate when compared with Method 4.

Our preliminary foraminifer data from the Toarcian reported here extends the range of $H$. kingakensis by approximately $10 \mathrm{~m}$ in Yorkshire compared to that reported by Hylton (2000, unpublished PhD thesis, University of Plymouth). Testing whether the Toarcian OAE is truly barren of foraminifera as reported by Hylton (2000, unpublished PhD thesis, University of Plymouth) awaits further study, but these early results suggest that studies where microfossils have been extracted using $\mathrm{H}_{2} \mathrm{O}_{2}$ may have inadvertently dissolved delicate species.

\section{CONCLUSIONS}

Our new freeze-thaw technique (Method 4) was the most successful technique for disaggregating mudrocks. Our results suggest that $\mathrm{H}_{2} \mathrm{O}_{2}$ is an unsuitable chemical for extracting delicate $\mathrm{CaCO}_{3}$ and pyritized microfossils because of the damage and dissolution it causes. Sodium hexametaphosphate, white spirit and Decon-90 caused no visible damage to the foraminifera. The only disadvantage 
of Method 4 as a single processing technique was that it left clay aggregates in the foraminifer-bearing fraction that had a dilution effect on the abundance of foraminifera, which makes microfossil picking more time consuming.

The technique of repetitive freeze-thaw combined with ultrasound treatment and using Decon-90 disaggregated at least 50\% of the original sample. The application of white spirit and sodium hexametaphosphate (Method 2) after Method 4 resulted in increased separation of the clay from the microfossil fraction and left the most diverse and abundant foraminifer assemblage with no evidence of chemical damage. Following Method 4 with Method 2 is quicker and more effective than using high-pressure washing to remove clays.

Our results demonstrate the importance of investigating the processing technique to maximize the preservation of microfossils and extract a true representation of the preserved foraminifer assemblage. We anticipate that the freeze-thaw method could be the basis of further development of a foraminifer extraction process across a wide range of sedimentary deposits.

\section{ACKNOWLEDGEMENTS}

This work was funded by a National Environment Research Council studentship awarded to A. E. Kennedy. K. Brand, B. A. Caswell, A. Cameron and C. Murray are thanked for their help with sampling in the field. We would like to thank the British Geological Survey for their assistance in processing mudrocks and help with identification, especially J. E. Flint, S. G. Molyneux, J. B. Riding and I. P. Wilkinson. J. Gregory and A. Gale are thanked for suggesting the idea of testing the freeze-thaw method. We thank D. Johnson for help with the SEM. Lastly, we would like to thank reviewers M. Williams and P. Copestake, whose comments helped to improve this manuscript.

\section{Manuscript received 14 August 2013 \\ Manuscript accepted 16 December 2013 \\ Scientific Editing by Alan Lord}

\section{REFERENCES}

Aldridge, R.J. 1990. Extraction of Microfossils. In Briggs, D. E. G. \& Crowther, P. R. (Eds), Palaeobiology - A synthesis. Blackwell Scientific Publications, Oxford, 502-504.

Caswell, B.A. \& Coe, A.L. 2013. Primary productivity controls on opportunistic bivalves during Early Jurassic oceanic deoxygenation. Geology, 41: 1163-1166.

Duffield, S.L. \& Warshauer, S.M. 1979. An integrated study of Mid-Appalachian subsurface shales (Upper Devonian): conodont biostratigraphy and ostracode paleoecology. Geological Society of America Abstracts with Programs, 11: 10-11.
Gräfe, K.U. 2005. Benthic foraminifers and palaeoenvironment in the Lower and Middle Jurassic of the Western Basque-Cantabrian Basin (Northern Spain). Journal of Iberian Geology, 31: 217-233.

Green, O.R. 2001. A Manual of Practical Laboratory and Field Techniques in Palaeobiology. Kluwer Academic, London, 538pp.

Hammer, O. \& Harper, D.A.T. 2006. Paleontological Data Analysis. Wiley-Blackwell, Oxford, 368pp.

Hanken, N.-M. 1979. The use of sodium tetraphenylborate and sodium chloride in the extraction of fossils from shales. Journal of Paleontology, 53: 738-741.

Hanna, G.D. \& Church, C.C. 1928. Freezing and thawing to disintegrate shales. Journal of Paleontology, 2: 131.

Hinchey, J.V. \& Green, O.R. 1994. A guide to the extraction of fossil diatoms from lithified or partially consolidated sediments. Micropalaeontology, 40, 368-372.

Hodgkinson, R.L. 1991. Microfossil processing: a damage report. Micropaleontology, 37, 320-326.

Howarth, M.K. 1992. The Ammonite Family Hildoceratidae in the Lower Jurassic of Britain. Monograph of the Palaeontographical Society, London, 145, 106pp.

Kemp, D.B., Coe, A.L., Cohen, A.S. \& Schwark, L. 2005. Astronomical pacing of methane release in the Early Jurassic period. Nature, 437: 396-399.

Kemp, D.B., Coe, A.L., Cohen, A.S. \& Weedon, G.P. 2011. Astronomical forcing and chronology of the early Toarcian (Early Jurassic) oceanic anoxic event in Yorkshire, UK. Paleoceanography, 26, 1-17.

Moullade, M., Tronchetti, G. \& Bellier, J.-P. 2005. The Gargasian (Middle Aptian) strata from Cassis-La Bédoule (Lower Aptian historical stratotype, SE France): planktonic and benthic foraminiferal assemblages and biostratigraphy. Carnets de Géologie/Notebooks on Geology, Article 2005/02, 20. Available online: http://paleopolis.rediris.es/cg/CG2005_A02/

Pingitore, Jr, N. E., Fretzdorff, S.B., Seitz, B.P., Estrada, L.Y., Borrego, P.M., Crawford, G.M. \& Love, K.M. 1993. Dissolution kinetics of $\mathrm{CaCO}_{3}$ in common laboratory solvents. Journal of Sedimentary Research, 63: 641-645.

Pojeta, Jr, J. \& Balanc, M. 1989. Freezing and thawing of fossils. In Feldmann, R. M., Chapman, R. E. \& Hannibal, J. T. (Eds), Paleotechniques. The Paleontological Society Special Publication, 4: 223-226.

Reolid, M., Sebane, A., Rodriguez-Tovar, F.J. \& Marok, A. 2012. Foraminiferal morphogroups as a tool to approach the Toarcian Anoxic Event in the Western Saharan Atlas (Algeria). Palaeogeography, Palaeoclimatology, Palaeoecology, 323-325: 87-99.

Sohn, I.G. 1961. Techniques for preparation and study of fossil ostracodes. In Moore, R. C. (Ed.), Treatise on Invertebrate Paleontology. Part Q; Arthropods 3. Geological Society of America and the University of Kansas, Boulder, Colorado and Lawrence, Kansas, 442pp.

Sohn, I.G., Berdan, J.M. \& Peck, R.E. 1965. Ostracods. In Kummel, B. \& Raup, D. (Eds), Handbook of Paleontological Techniques. W.H. Freeman and Co, San Francisco, 852pp.

Then, D.R. \& Dougherty, B.N. 1983. A new procedure for extracting foraminifera from indurate organic shale. Geological Survey of Canada, 83-1B: 413-414. 


\section{BiotecMicroslides}

Little Lower Ease

Cuckfield Road

ANSTY

West Sussex RH17 5AL

England

Tel/Fax: +44 (0)1444 452282

Email: sales@biotecmicroslides.co.uk

Web: www.biotecmicroslides.co.uk

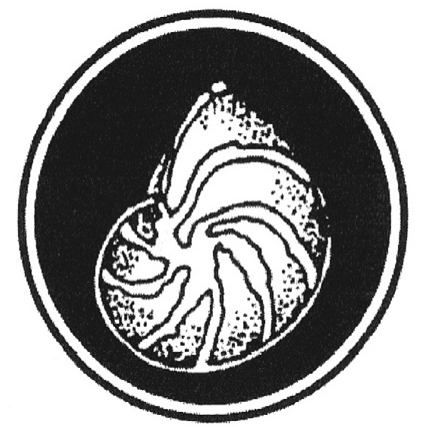

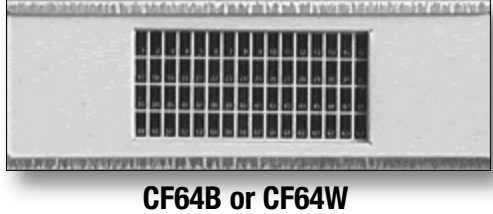

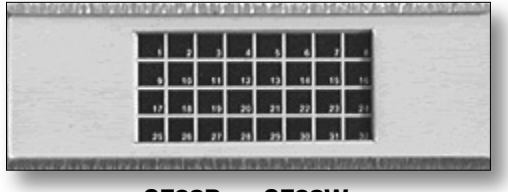

CF32B or CF32W

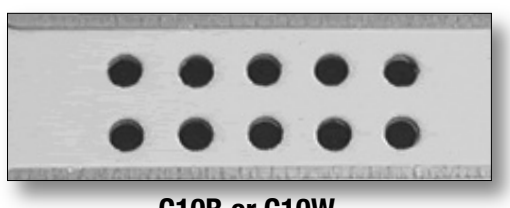

C10B or C10W
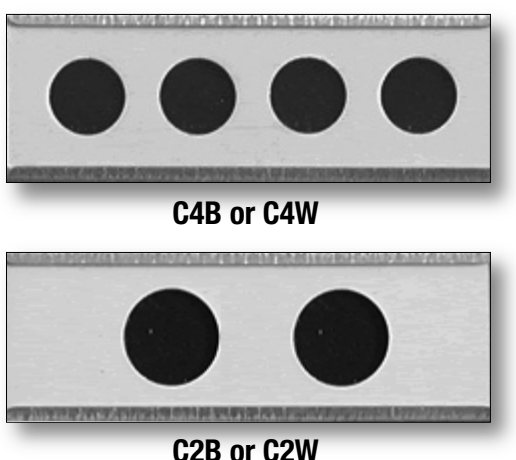

C2B or C2W

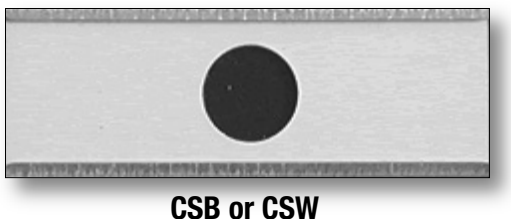

CSB or CSW

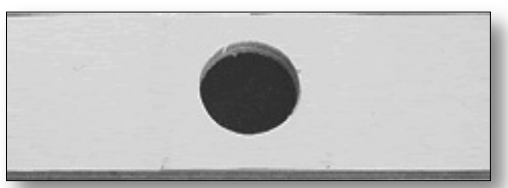

CSBDD or CSWDD
BiotecMicroslides has been manufacturing slides for the storage of microfossils and small zoological and botanical specimens since 1974 .

Slides, with either black or white cell backgrounds are available in cardboard with aluminium holder and glass coverslide. Also available to order are double-depth single-cell slides with paper tops and either acetate or glass coverslip.

Slide dimensions 3" x 1" (76mm x 27mm)

- Pine Storage Cabinets (28 drawers) with or without glazed door

- Picking trays $3 \frac{3 / 4}{4} \times 3^{1 / 4}$

(97mm x 84mm)

- 00 Picking brushes with sable or synthetic bristles 